\title{
PŘEDBĚŽNÁ INTERPRETACE OBJEKTŮ POLNÍHO OPEVNĚNÍ NĚMECKÉHO WEHRMACHTU U PASOHLÁVEK (OKR. BRNO-VENKOV)
}

\author{
JIŘÍ ZUBALÍK - BALÁZS KOMORÓCZY - MIROSLAV LUKÁŠ - MAREK VLACH
}

\begin{abstract}
Abstrakt: Při výzkumech u obce Pasohlávky (okr. Brno-venkov) a pod Hradiskem u Mušova se podařilo odkrýt také pozůstatky polního opevněni ze závěru druhé světové války. Bylo součástí delšího fortifikačního systému, který vybudovala německá armáda na konci dubna 1945. Sovětská armáda dosáhla nèmeckých pozic 23. dubna, poté započaly dlouhé boje, které se na lokalitě protáhly až do 7. května. Příspěvek se zaměřruje na predběžné vyhodnoceni funkce 86 zahloubených objektù, které je možno dle tvarových a rozměrových charakteristik rozdělit do několika kategorii. S pomoci dobových pisemných pramenů (ženijních př́ruček) lze objekty dále interpretovat. Nejběžnějšim typem byly okopy pro dva stojici střelce, dokumentován byl také kryt pro spojaře či okopy pro ležici nebo klečici střelce, okopy pro družstvo, kulomet nebo minomet.
\end{abstract}

Klíčová slova: jižni Morava - polni fortifikace - archeologie moderních konfliktů - odkryv.

Preliminary Interpretation of Wehrmacht Field Fortification Features near Pasohlávky (Brno-venkov District)

Abstract: Archaeological research near the village of Pasohlávky (Brno-venkov district) and below Hradisko $u$ Mušova has yielded, among other things, the remains of a field fortification from towards the end of the Second World War. It was part of a longer fortification system built by the German army in late April 1945. The Soviet army reached the German positions on 23 April 1945, marking the beginning of extended military engagement in the area that lasted until 7 May 1945. This paper seeks to make a preliminarily assessment of the functions of 86 sunken features. They may be divided into several categories, based on their shapes and dimensions. The features can be further interpreted in the light of period written sources (field military engineer manuals). Most common were trenches used as firing positions for two standing soldiers, a dugout for communications, and trenches used for kneeling or prone soldier, while trenches for squads, a machine gun position and a mortar position were identified as well.

Key words: southern Moravia - field fortifications - modern conflict archaeology - excavation.

\section{Úvod}

Od konce druhé světové války, která zasáhla také území naší republiky, uběhlo již víc než 70 let a vzpomínky př́imých účastníků se pomalu vytrácí. Brzy bude možno ji poznat pouze zprostředkovaně skrz dobové písemné, fotografické a filmové prameny. Navíc se ke studiu nabízí také dochované hmotné prameny. Vyjma movitých artefaktů (zbraní, vozidel, součástek výstroje), které jsou poměrně dobře známy, je možno zkoumat také množství nemovitých artefaktů, především pozůstatků polních fortifikací, táborů, letišt' apod. Tomuto druhu pramenů nebylo odbornou veřejností donedávna věnováno příliš pozornosti, přitom se jedná o oblast bádání, která nabízí ohromný potenciál k poznání konkrétních válečných událostí, jež přitom nemusí být známy z historických pramenů (Moshenska 2012, 2-5; Saunders 2010, 159, 175).

Tento článek je zaměřen na předběžné vyhodnocení pozůstatků polního opevnění ze závěru druhé světové války, které bylo nalezeno při záchranných výzkumech v okolí Pasohlávek (okr. Brno-venkov) a pod vrchem Hradisko (Burgstall) u Mušova. Bude zde popsána nálezová situace a základní typy objektů, které lze na lokalitě nalézt. Detailnější vyhodnocení bude následovat v rámci disertační práce, která bude věnována studiu válečných pozůstatků na jižní Moravě.

\section{Přírodní prostředí}

Geomorfologicky spadá území do provincie Západní Karpaty, subprovincie Vněkarpatské sníženiny, oblasti Západní vněkarpatské sníženiny, celku Dyjsko-svratecký úval. Zastavěné území obce a severní část k. ú. Mušov spadá do podcelku Dyjsko-svratecká niva. Severozápadní 
část k. ú. Pasohlávky náleží k podcelku Drnholecká pahorkatina, okrsku Olbramovická pahorkatina. Jižní část k. ú. Mušov se nalézá v podcelku Dunajovické vrchy, okrsku Dunajovická sníženina.

Geologické podloží je v dotčeném prostoru dvojího druhu: střídají se v něm souvislé plochy nesoudržných štěrkopísků doprovázených jemnými písky, resp. plochy neogenních jílů. Tato skladba je obecně typickou geologickou stavbou v celém Dyjsko-svrateckém úvalu. Na geologické podloží dosedá místy nepatrná, místy až $0,8 \mathrm{~m}$ mocná šedohnědá pevná hlína. Nad ní, resp. v místech, kde chyběla, príímo nad geologickým podložím, se nacházela ca $0,5-0,7 \mathrm{~m}$ mocná černohnědá ornice.

\section{Historické prameny}

Při studiu recentních konfliktů hrají historické prameny nezanedbatelnou úlohu (Rak 2013, 117-119). Přitom lze tyto (převážně písemné) prameny rozdělit do dvou kategorií - na prameny historické povahy a na prameny technické povahy. Do první kategorie lze zařadit např́íklad kroniky obcí dotčených bojovými událostmi (pokud se dochovaly) a materiály, které vytvořily štáby bojujících jednotek - především bojové deníky jednotlivých divizí a mapy či plánky zachycující pozice těchto jednotek. Druhou kategorii pak reprezentují ženijní příručky popisující vzhled a princip výstavby polních fortifikací. Při identifikaci artefaktů mohou pomoci také příručky s údaji o tvaru a rozměrech výstrojních součástek, zbraní nebo nábojů a nábojnic.

Pro sledovanou oblast je k dispozici několik pramenů. Především se jedná o polní deníky sovětských střeleckých divizí, konkrétně 141., 375. a 409. střelecké divize. Tyto deníky zachycují den po dni bojovou aktivitu konkrétní divize, pozice pluků spadajících pod tyto divize, ztráty, které divize utrpěla i způsobila, materiálové zajištění i počasí. Využít lze také mapový materiál 7. gardové armády, jejíž jednotky bojovaly v okolí Pasohlávek od samotného začátku, a 53. armády, která některé své jednotky do oblasti stáhla po dobytí Brna 28. dubna 1945 (obr. 1). Všechny tyto materiály jsou volně dostupné na internetových stránkách http://pamyat-naroda.ru. Některé informace lze čerpat také z kroniky obce Pasohlávky, která se sice nedochovala, ale je citována v diplomové práci Ireny Bortlíkové (1988, 35-36). Mušovská kronika má stránky věnované období druhé světové války vytrhány.

Co se technicky zaměřených pramenů týče, $\mathrm{k}$ dispozici je především německá příručka Bildheft Neuzeitlicher Stellungsbau ve dvou vydáních - starší je ze září 1942, doplněná v březnu 1943 (dostupná v anglickém překladu z 60. let), mladší vyšla v červnu 1944. V těchto př́íručkách je vyobrazen ideální vzhled různých typů polních fortifikací (jak pro pěchotu, tak i pro těžší zbraně jako minomety nebo děla), uvádějí také rozměry objektů, dobu výstavby, množství vytěžené zeminy, potřebný materiál (např. dřevěné desky) a nářadí a také průběh práce. Kromě německých materiálů lze v omezené míře využít také americké zpravodajské materiály, například Special Series, No. 9: The German Squad in Combat z ledna 1943 nebo Technical Manual: Handbook on German Military Forces z března 1945. První př́ručka se zabývá organizací pěšího družstva v různých situacích, druhá se věnuje wehrmachtu komplexně - od struktury přes taktické náležitosti až po techniku a výbavu. Obě příručky jsou pak pro nás zajímavé díky tomu, že popisují základy situování a organizování obrany německé pěchoty od úrovně družstva až po úroveň praporu.

\section{Boje o Hradisko}

Válečné události se do okolí Pasohlávek a Mušova přenesly až po 20. dubnu 1945, kdy se ustupující německý wehrmacht opevnil na levém břehu řeky Dyje v prostoru od Drnholce až po Pasohlávky, dále se obranná linie stáčela na sever směrem k Pohořelicím. Ve sledované oblasti vybudovali obranný systém polního opevnění vojáci 357. pěší divize, kteří spadali pod Skupinu armád jih pod velením generálporučíka Hainze von Gyldenfeldt. 


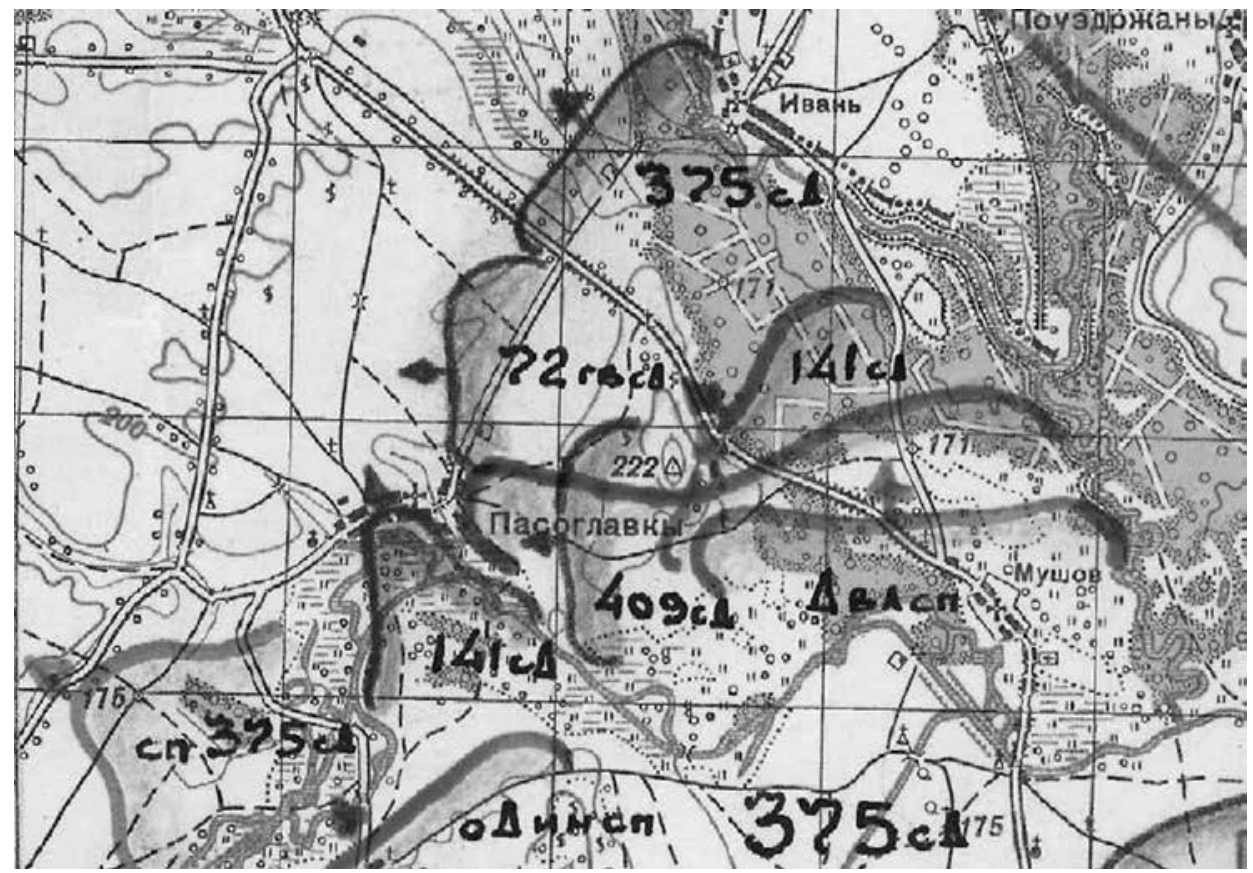

Obr. 1. Detail štábní mapy 7. gardové armády zachycující situaci v okolí Hradiska (kóta 222) a Pasohlávek (východně od kóty 222) ve dnech 23. až 27. dubna 1945. Převzato z https://pamyat-naroda.ru/warunit/7\%20ГвА/.

Abb. 1. Detail der Stabskarte der 7. Gardearmee mit Darstellung der Situation in der Umgebung von Hradisko (Kote 222) und Pasohlávky (östlich von Kote 222) an den Tagen 23. bis 27. April 1945. Entnommen aus https://pamyat-naroda.ru/ warunit $/ 7 \% 20$ Г ВА/.

Rudá armáda, konkrétně 375. střelecká divize spadající pod 2. ukrajinský front pod velením maršála Rodiona Malinovského, dosáhla tohoto prostoru 23. dubna. Mušov byl obsazen již v tento den, stejně jako Hradisko, které bylo dobyto obchvatem z východu přes lužní les. Při této operaci divize ztratila 129 mužů (Holečková 2014, 311). Poté zde obě strany přisunuly řadu dalších jednotek - Němci sem stáhli především tankový sbor Feldhernhalle, jehož součástí byl také oddíl těžkých tanků Feldhernhalle 2, vyzbrojený i těžkými tanky PzKpfw VI Ausf. B Königstiger. Rudá armáda posílila mimo jiné o 141. a 409. střeleckou divizi, které se zapojily do následujících bojů o Hradisko (Holečková 2014, 311; Schildberger 1987, 202, 211; Память народа::Поиск документов частей 2016).

Další bojové akce na lokalitě vypukly 27. dubna. Rudá armáda vyrazila dobýt Pasohlávky, a současně se wehrmacht pokusil ze severu dobýt Hradisko. Zatímco sovětská 141. střelecká divize byla ve svém pokusu úspěšná a dobyla jihovýchodní okraj Pasohlávek, německý útok byl tohoto dne ještě odražen. Proto Němci další den protiútok zopakovali, a za pomoci tanků vytlačili Rusy jak z Pasohlávek, tak snad také z Hradiska. Již ale v noci na 29. dubna podnikla Rudá armáda protiútok a dobyla Hradisko zpět. Následující den sovětské jednotky zaútočily na Pasohlávky, které se jim sice podařilo dobýt, ale opět byly vytlačeny pryč z obce (Holečková 2014, 311-312; Память народа::Поиск документов частей 2016).

Od 1. května byl na zdejším úseku fronty klid, obě strany sbíraly síly a budovaly a zesilovaly své postavení. Německá 357. pěší divize držela Pasohlávky a jejich blízké okolí, sovětské jednotky (141. a 409. střelecká divize) se opevňovaly na západních svazích Hradiska. Obě strany byly od sebe vzdáleny zhruba jeden kilometr. Závěrečné boje o Pasohlávky vypukly až 7. května a souvisí se začátkem pražské operace. Sovětský útok odstartovala půlhodinová dělostřelecká 
př́íprava, mimo jiné i za účasti kat’uší, které snad byly umístěny na Hradisku (Bortlíková 1988, 35-36). Poté již zaútočila pozemní armáda, která v poměrně krátké době obsadila definitivně celou obec a rychle postupovala směrem dál do Čech (Holečková 2014, 312-313).

\section{Výzkumy na lokalitě}

Předložené objekty z druhé světové války byly zdokumentovány a exkavovány pracovníky Archeologického ústavu AV ČR, Brno, v. v. i., při záchranných a systematických výzkumech pod vedením Mgr. Balázse Komoróczyho mezi lety 1994 a 2016. Záchranné archeologické výzkumy probíhaly na levém břehu Dyje v katastrálním území obce Pasohlávky a zaniklé obce Mušov. Konkrétně se jednalo o ZAV při výstavbě kanalizace a ČOV v roce 2002 (Pasohlávky 2002), při velkoplošných skrývkách v rámci realizace projektu Rekreační bydlení Pasohlávky, Laguna - Resort, při výstavbě páteřní komunikace v budoucí lázeňské zóně v Pasohlávkách Pasohlávky 2008. V roce 2009 pak proběhl předstihový záchranný archeologický výzkum části plochy určené k výstavbě aquaparku - tzv. Etapa 2 a Územní rezerva pro etapu 2. O dva roky později byl proveden záchranný archeologický výzkum při stavbě Thermal Pasohlávky - multifunkční objekt a infrastruktura na poloostrově. Objekty ze systematických výzkumů pocházejí z lokality Mušov - Hradisko.

Záchranné archeologické výzkumy probíhaly standardní metodou. Po odstranění recentní ornice o mocnosti zhruba $20 \mathrm{~cm}$ byla celá stavbou dotčená trasa skrývána strojovou mechanizací typu UDS s hladkou lžící. Přitom byla prováděna systematická prospekce odstraňovaných uloženin formou trvalého vizuálního a detektorového průzkumu. Plošný výzkum byl realizován u všech uloženin a výkopů, které bylo za daných podmínek dochování archeologických objektů možné rozlišit, at' již na úrovni kulturní vrstvy nebo na povrchu geologického podloží. Mocnost nadložních vrstev odstraněných při záchranném výzkumu mechanizací UDS se pohybovala mezi 0,3 a $1,5 \mathrm{~m}$. Odkryv objektů probíhal standardní metodou ručního kopání a následné dokumentace (ovšem poměrně nesoudržné geologické podloží nebo případná vyšší hladina spodní vody některé postupy archeologické práce významně determinovaly, především co se týká preparace objektů).

\section{Nálezová situace}

Na lokalitě bylo zachyceno dohromady 99 objektů, které jsou rozprostřeny v délce $1,7 \mathrm{~km}$ od východního okraje Pasohlávek až po jižní úpatí Hradiska. Veškeré objekty byly fotograficky dokumentovány a zaměřeny pomocí totální stanice, kresebně bylo dokumentováno dvanáct objektů. Bylo exkavováno celkem 55 objektů, přičemž se jednalo převážně o objekty, které byly při průzkumu detektorem pozitivní na kovové signály.

Většina dokumentovaných objektů se nachází ve dvou velkých skupinách, které jsou ale dány spíše rozsahem záchranných výzkumů než skutečnou situací na lokalitě. Největší skupina, čítající 52 objektů, se rozprostírá přímo na jižním úbočí Hradiska. Druhá velká skupina je registrována zhruba 500 až 600 metrů jihovýchodním směrem od Pasohlávek, přibližně 1300 metrů západním až jihozápadním směrem od první skupiny. Zde je v rámci liniových výzkumů zaznamenáno 29 objektů. Mezi těmito dvěma skupinami bylo odkryto ještě třetí malé seskupení o šesti objektech. Zbylé objekty jsou rozmístěny solitérně (obr. 2).

Při současném stavu poznání je bližší analýza prostorových vztahů mezi objekty poměrně obtížná. Komplikace působí např́íklad poměrně útržkovitě zkoumaná plocha v širším okolí Hradiska a Pasohlávek, lze předpokládat, že řada objektů stále čeká na své odkrytí. Orientaci také ztěžuje fakt, že vzhledem k výše popsanému průběhu bojových akcí lze předpokládat minimálně dvě fáze budování polního opevnění, část objektů může být také vyhloubena sovětskou armádou. Tyto analýzy budou předmětem dalšího bádání.

Předběžně lze zejména objekty pod Hradiskem považovat za předsunutou pozici před hlavní obrannou linií (hauptkampflinie), která je známa z Hradiska. Zde se už při dřívějších vý- 


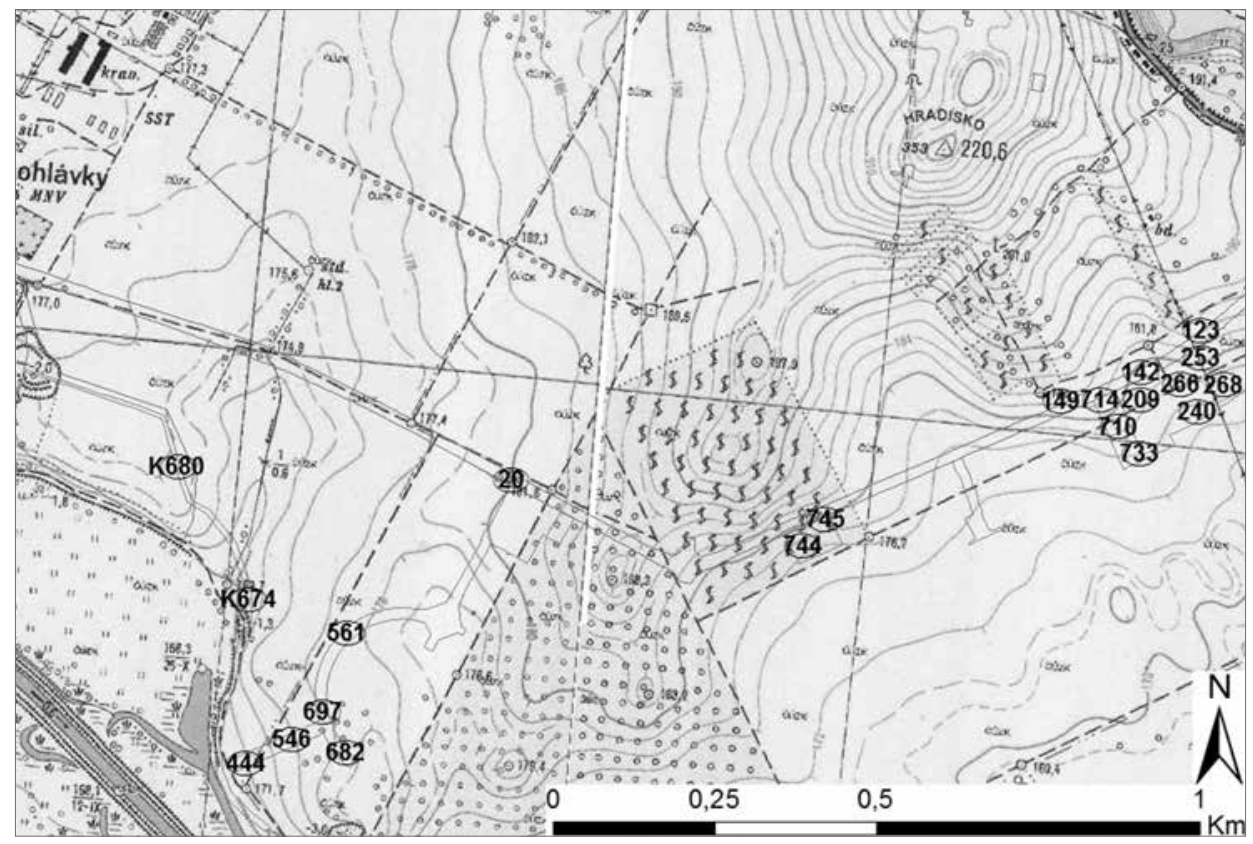

Obr. 2. Rozložení některých dokumentovaných objektů pod Hradiskem a u Pasohlávek. Jedna větší skupina je př́ímo pod Hradiskem, druhá jihovýchodně od Pasohlávek, třetí malá je uprostřed. Podkladová mapa je topografická mapa z roku 1952. Převzato z http://archivnimapy.cuzk.cz/. Plán J. Zubalík a ARÚ AV ČR, Brno, v. v. i.

Abb. 2. Verteilung einiger dokumentierter Objekte unterhalb von Hradisko und bei Pasohlávky. Eine größere Gruppe befindet sich direkt unterhalb von Hradisko, die zweite südöstlich von Pasohlávky, eine kleine dritte befindet sich in der Mitte. Als Vorlage diente eine topographische Karte aus dem Jahr 1952. Entnommen aus http://archivnimapy.cuzk.cz/. Planskizze J. Zubalík und Archäologisches Institut der Akademie der Wissenschaften der Tschechischen Republik Brno, öffentliche Forschungseinrichtung.

zkumech odkryla souvislá zákopová linie (Komoróczy 2000, 146, obr. 3 na s. 147). Organizace německé obrany na hlavní obrannou linii a předsunuté pozice je známá z amerických př́ruček. Předsunutá pozice se měla umístovat 2000 až 5000 stop (přibližně 600 až 1500 metrů) před hlavní pozici. Důraz byl kladen na efektivní využití kulometů a pušek. Při silném nepřátelském tlaku se obránci měli stáhnout na hlavní obrannou linii (War Department 1943, 56-59; 1945, IV-20-IV-21).

\section{Typologie objektů}

Při současném stavu poznání je interpretace některých objektů obtížná, především z důvodu neznámé hloubky u řady objektů. Kvůli tomu může být nesnadné rozlišit od sebe např́iklad okopy pro ležící střelce od okopů pro dva stojící střelce - oba typy jsou obdélníkového tvaru a podobných rozměrů, liší se hlavně hloubkou objektu (viz dále). Přes tyto problémy lze identifikovat několik základních typů objektů, které se na lokalitě vyskytují. Př́i následujícím výčtu bude nejprve uveden popis konkrétního typu objektu známý z prŕíruček (pokud je zmiňován), poté na několika př́íkladech bude ukázán vzhled tohoto typu na lokalitě.

\section{Okop pro ležicího střelce}

Jedná se o nejjednodušší typ polního opevnění, také se nejrychleji vykope. Má přibližně obdélný nebo oválný půdorys a dosahuje hloubky maximálně 0,5 metrů (obr. 3:A). Tento typ 

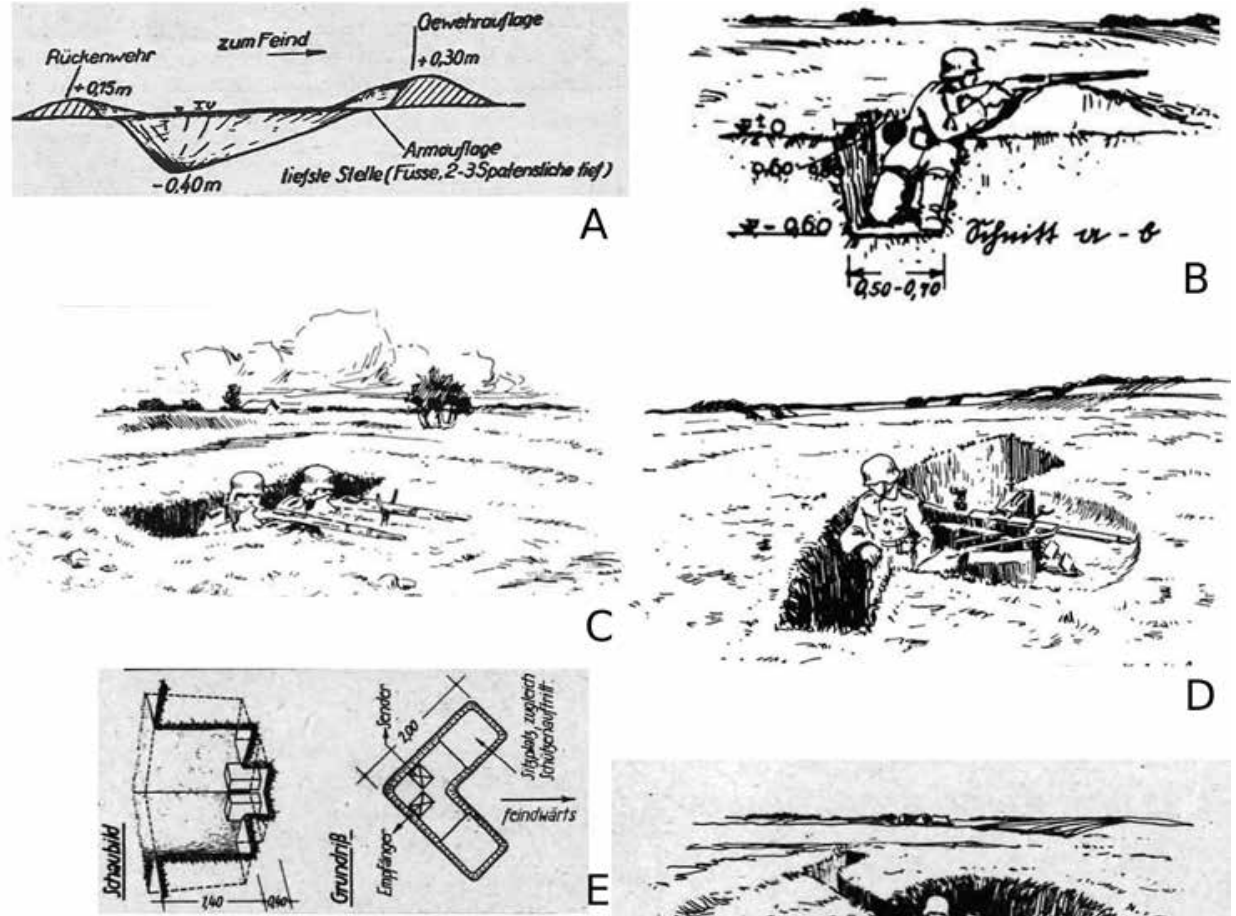

$\mathrm{E}$
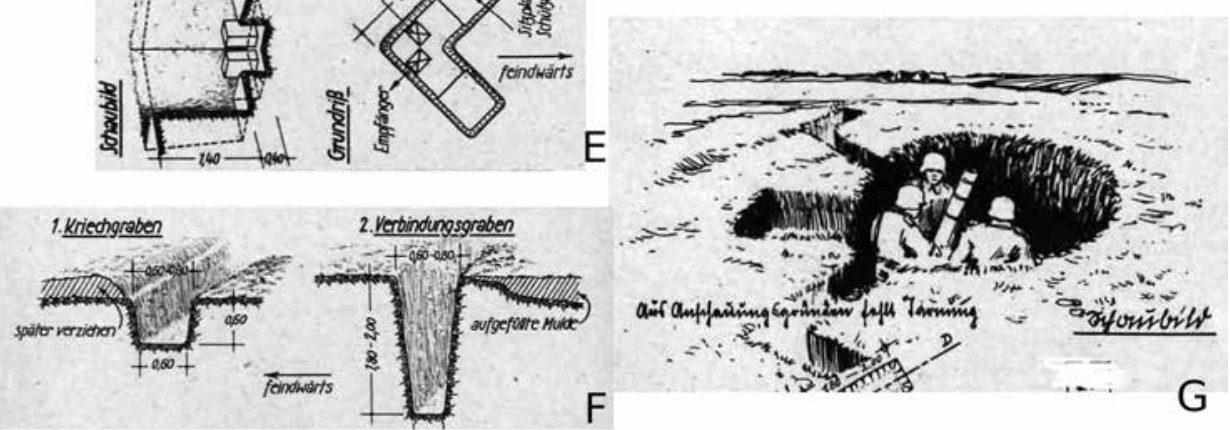

Obr. 3. Ilustrační vyobrazení některých typů okopů z dobových příruček. A - okop pro ležícího střelce; B - okop pro klečícího střelce; C - okop pro dva stojící stř̌elce; D - okop pro kulomet; $\mathrm{E}$ - kryt pro spojaře; F - řez spojovacím zákopem pro přikrčené a stojící vojáky; G - okop pro střední minomet. Podle Töpfer 2016 (A), Bellona Publications Limited 1969 (B, C, D) a Oberkommando des Heeres 1944 (E, F, G).

Abb. 3. Illustrative Darstellung einiger Gräbentypen aus zeitgenössischen Handbüchern. A - Graben für einen liegenden Schützen; B - Graben für einen knienden Schützen; C - Graben für zwei stehende Schützen; D - Graben für Maschinengewehr; E - Unterstand für Funker; F - Profilschnitt durch einen Verbindungsgraben für geduckte und stehende Soldaten; G - Graben für mittleren Minenwerfer. Nach Töpfer 2016 (A), Bellona Publications Limited 1969 (B, C, D) und Oberkommando des Heeres 1944 (E, F, G).

okopu zmiňuje Harry Töpfer, který ve své práci vycházel z několika originálních německých př́ruček (Töpfer 2016, 26).

Obdélné objekty jsou nejčastěji se vyskytujícím typem, dohromady jich je dokumentováno šedesát. Problémem je, že u 25 objektů není známa hloubka, což ztěžuje jejich interpretaci. Z objektů se známou hloubkou lze do kategorie okopů pro ležícího střelce zařadit pouze dva objekty. Oba se nachází pod Hradiskem. Délka objektu č. 266 je necelých $200 \mathrm{~cm}$, šířka činí $60 \mathrm{~cm}$ a hloubka od povrchu skrývky dosahuje $20 \mathrm{~cm}$. Objekt č. 209 dosahuje délky $230 \mathrm{~cm}$, šířky $70 \mathrm{~cm}$ a hloubky $23 \mathrm{~cm}$ (obr. 4). Teoreticky by tento typ mohl představovat ještě objekt č. 730 o délce $220 \mathrm{~cm}$, šířce necelých $60 \mathrm{~cm}$ a hloubce $20 \mathrm{~cm}$, ale má tvar nepravidelného obdélníku s protaženým výklenkem $\mathrm{v}$ jedné $\mathrm{z}$ užších stran. 


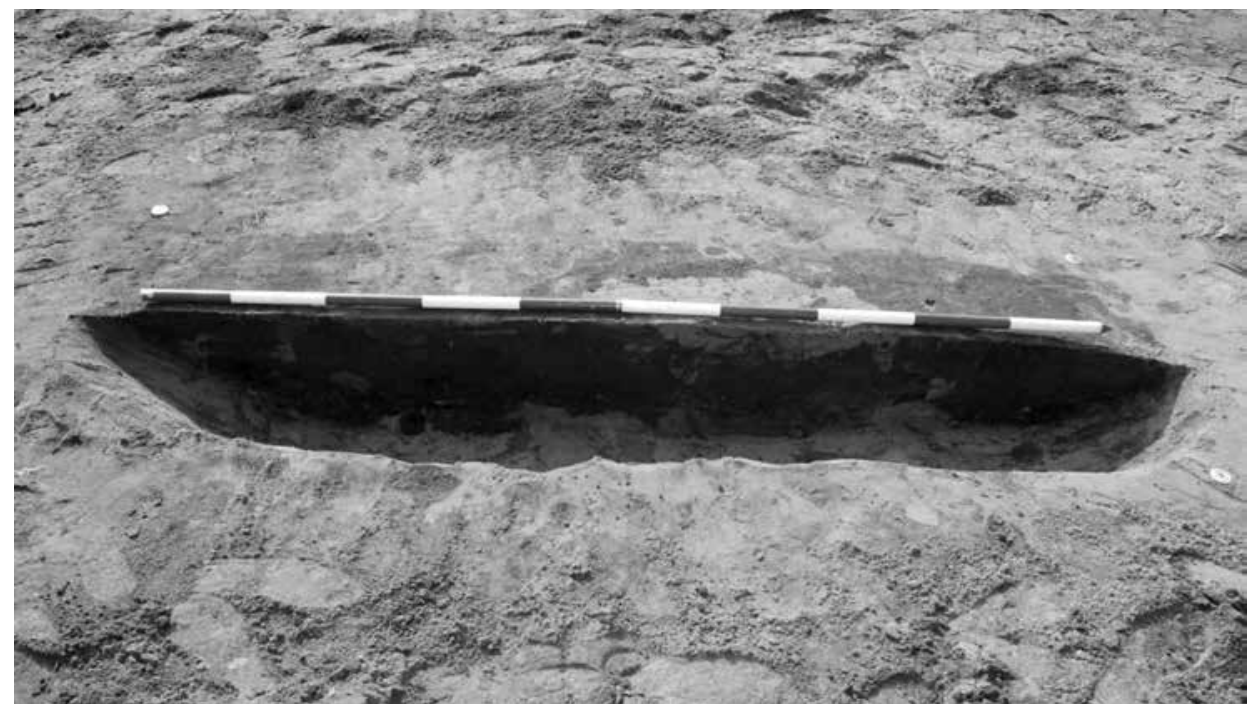

Obr. 4. Objekt č. 209 - okop pro ležícího stř̌elce. Foto ARÚ AV ČR, Brno, v. v. i.

Abb. 4. Objekt Nr. 209 - Graben für einen liegenden Schützen. Foto Archäologisches Institut der Akademie der Wissenschaften der Tschechischen Republik Brno, öffentliche Forschungseinrichtung.

\section{Okop pro klečícího/stojícího střelce}

Také velice jednoduchý typ okopu pro jednoho vojáka. Ve starší příručce se vyskytuje ve dvou variantách - pro klečícího a pro stojícího střelce, přibližně o čtvercovém tvaru a délce strany kolem $70 \mathrm{~cm}$. Hloubka první varianty se uvádí $60 \mathrm{~cm}$ (obr. 3:B), u druhé varianty až $160 \mathrm{~cm}$ (Bellona Publications Limited 1969, 8-9). V mladší př́íručce je pouze varianta pro stojícího střelce, ale s kruhovým půdorysem o průměru $70 \mathrm{~cm}$ při okraji, $50 \mathrm{~cm}$ u dna. Jeden muž měl tento okop vykopat za tr̆i hodiny (Oberkommando des Heeres 1944, blatt 5).

Ani jeden objekt na lokalitě nebyl kruhový o rozměrech do $70 \mathrm{~cm}$, dokonce se zde nevyskytují ani malé čtvercové objekty. Pouze dva obdélné objekty mohly být díky svým menším rozměrům okopem pro jednoho muže. Prvním je objekt č. 491 nacházející se jihovýchodně od Pasohlávek, který dosahuje délky $82 \mathrm{~cm}$ a šířky $57 \mathrm{~cm}$, hloubka výkopu není známa (obr. 5). Druhý objekt č. 511 je dlouhý přibližně $90 \mathrm{~cm}$ a široký necelých $50 \mathrm{~cm}$, hloubka také není známa.

\section{Okop pro dva klečící/stojící střelce}

Podlouhlá forma jednoduchých fortifikací pro dva, prrípadně tři střelce. Také jsou uváděny ve více variantách. $\mathrm{V}$ obou př́ručkách se nacházejí tyto okopy ve variantě $\mathrm{s}$ ochranou proti tankům, které se dělí dle tuhosti zeminy, do níž jsou hloubeny. Pokud byla zemina pevná, měly mít okopy pravoúhlý tvar písmena „L“s délkou stěny $200 \mathrm{~cm}$, šířkou $80 \mathrm{~cm}$ a hloubkou $140 \mathrm{~cm}$ u střeleckých stupňů (na obou koncích objektu) a 180 až $200 \mathrm{~cm}$ v místě, kde se měli vojáci krýt (ve střední části objektu). Dva muži měli tuto variantu okopu vykopat za pět hodin. Pokud nebyla zemina př́liš odolná, měli vojáci budovat pouze obloukovitě prohnutou variantu s vrcholem vyklenutí situovaným směrem od nepřítele. Délka objektu činí až $280 \mathrm{~cm}$, šířka $80 \mathrm{~cm}$ a hloubka opět $140 \mathrm{~cm}$ na obou koncích okopu (střelecký stupeň) a 180 až $200 \mathrm{~cm}$ ve střední části objektu. Dva muži měli tento okop připravit také za pět hodin (Bellona Publications Limited 1969, 8, 10; Oberkommando des Heeres 1944, blatt 5, blatt 7). Ve starší př́íručce z roku 1943 je vyobrazen také jednodušši typ bez ochrany proti tankům, rovněž ve dvou variantách - obdélného půdorysu a prohnutá varianta s vrcholem vyklenutí směrovanou směrem k nepříteli (obr. 3:C). Šířka 


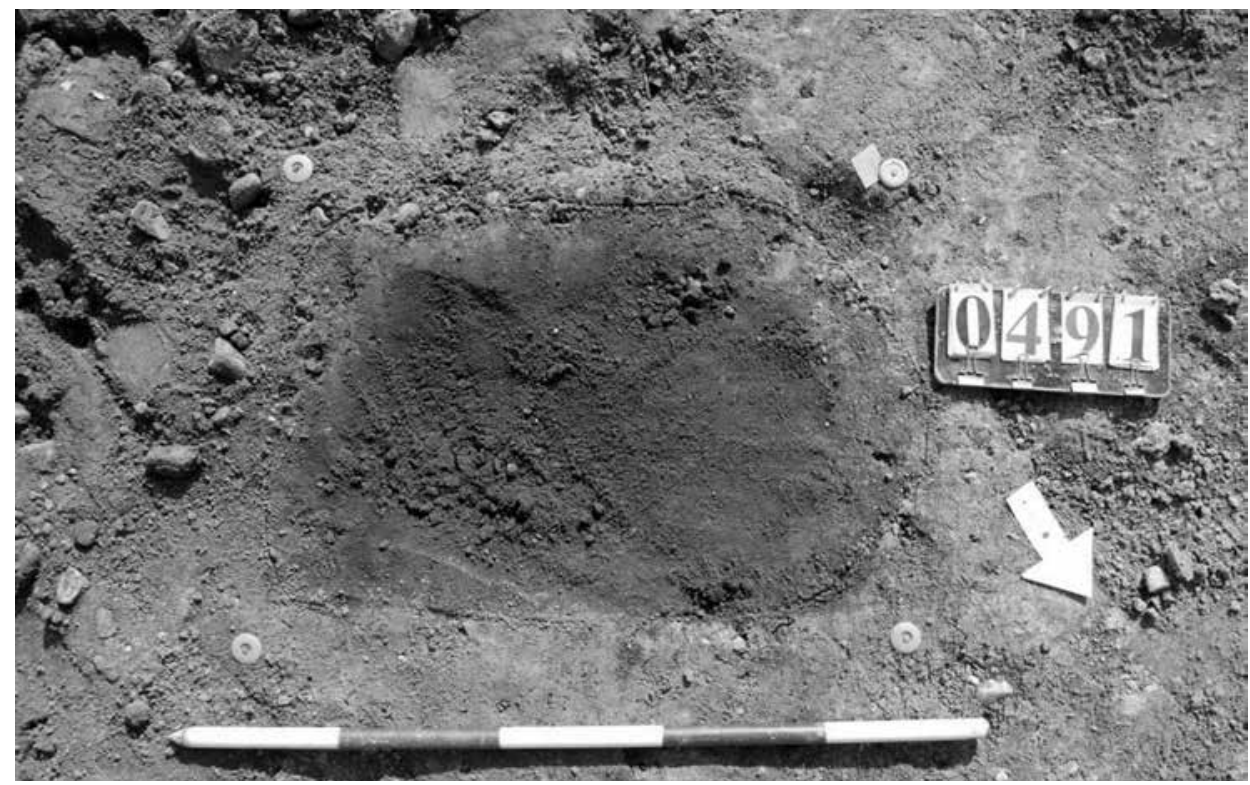

Obr. 5. Objekt č. 491 - okop pro stojícího nebo klečícího střelce. Foto ARÚ AV ČR, Brno, v. v. i.

Abb. 5. Objekt Nr. 491 - Graben für einen stehenden oder knienden Schützen. Foto Archäologisches Institut der Akademie der Wissenschaften der Tschechischen Republik Brno, öffentliche Forschungseinrichtung.
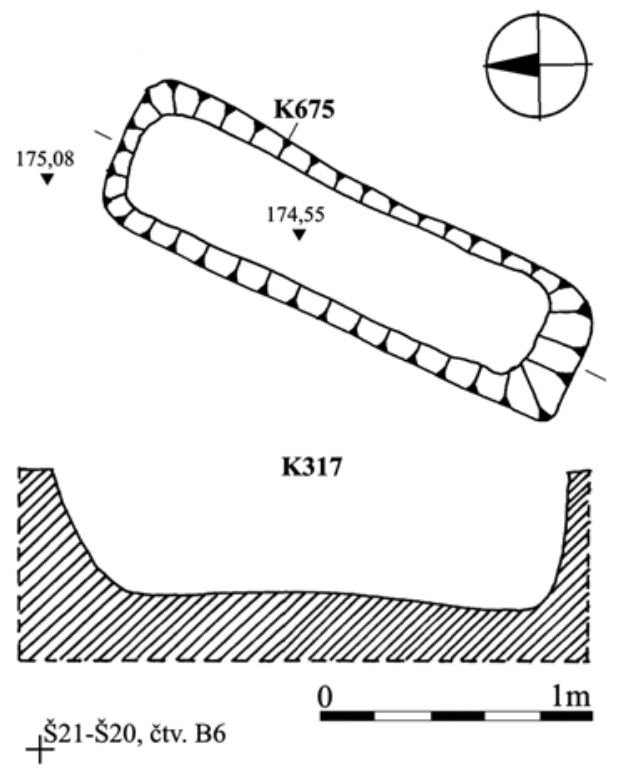

Obr. 6. Objekt č. K675 - okop pro dva střelce. Kresba ARÚ AV Čr, Brno, v. v. i.

Abb. 6. Objekt Nr. K675 - Graben für zwei Schützen. Zeichnung Archäologisches Institut der Akademie der Wissenschaften der Tschechischen Republik Brno, öffentliche Forschungseinrichtung. obou variant při okraji dosahuje $80 \mathrm{~cm}$, při dnu $40 \mathrm{~cm}$, dlouhé měly být $160 \mathrm{~cm}$ při okraji a $120 \mathrm{~cm}$ při dně. Oproti okopům s ochranou proti tankům je maximální hloubka menší, dosahuje pouze $160 \mathrm{~cm}$ (Bellona Publications Limited 1969, 11). Doba výstavby uvedena není, lze ovšem předpokládat, že bude o něco kratší než výše zmíněných pět hodin. V př́ípadě nedostatku času se mohly budovat i mělčí okopy pro dva klečící střelce (Töpfer 2016, 26).

Z celkového množství 70 obdélných objektů má 21 rozměry (včetně hloubky), které přibližně odpovídají tomuto typu okopu. Hloubka se přitom pohybuje od 40 do $80 \mathrm{~cm}$, nejčastěji kolem $50 \mathrm{~cm}$ (dohromady u $15 \mathrm{ob}-$ jektů), tři nejhlubší objekty mají hloubku 68 , 80 a 82 cm (obr. 6, obr. 9). Pravděpodobně se tedy častěji jedná o objekty pro dva klečící střelce. Dalších 25 objektů svou délkou a širŕkou také může odpovídat okopům pro dva stojící nebo klečící střelce, ale protože není u nich známa hloubka, nelze s jistotou říct, zda některé $\mathrm{z}$ nich nebyly okopem pro ležícího střelce. Pozoruhodný je poměrně velký rozptyl délky a šiřky - u patnácti objektů se 

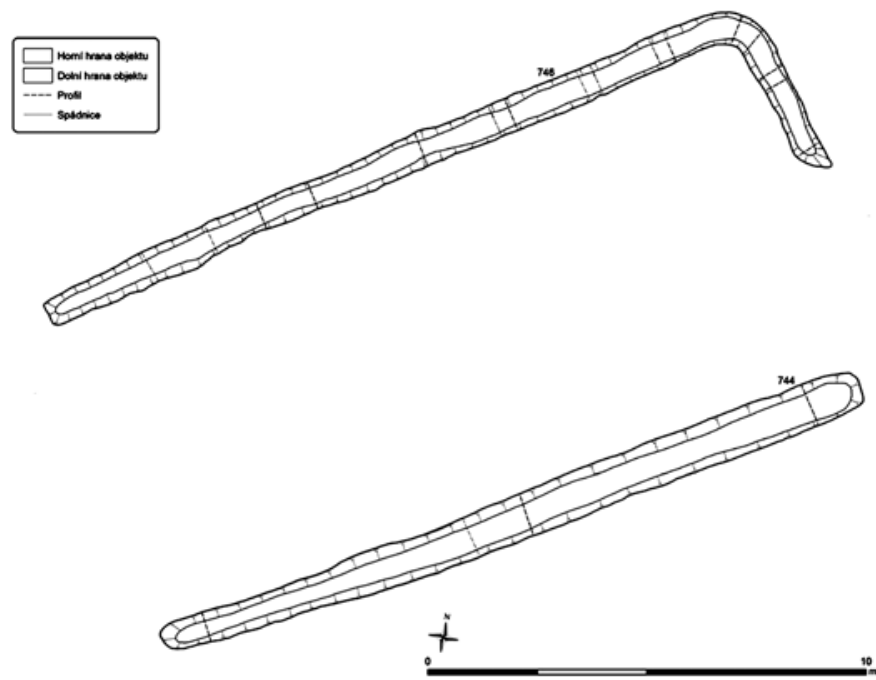

Obr. 7. Objekty č. 746 a 744 - okopy pro více střelců. Kresba ARÚ AV ČR, Brno, v. v. i.

Abb. 7. Objekte Nr. 746 und 744 - Gräben für mehrere Schützen. Zeichnung Archäologisches Institut der Akademie der Wissenschaften der Tschechischen Republik Brno, öffentliche Forschungseinrichtung.

pohybuje délka mezi 150 a $170 \mathrm{~cm}$ (tyto by odpovídaly okopům bez ochrany proti tankům). Pouze jeden objekt se přiblížil $\mathrm{k}$ délce $280 \mathrm{~cm}$ vyžadované u okopů s krytem proti tankům - dosáhl délky $270 \mathrm{~cm}$. U zbylých objektů se pohybuje délka zhruba od 120 do $150 \mathrm{~cm}$ (deset př́padů) a od 170 do $240 \mathrm{~cm}$ (20 př́ípadů). Šiřka je také poměrně variabilní, nejužší objekt měřil $40 \mathrm{~cm}$, nejširší $105 \mathrm{~cm}$. Na první pohled je tedy zř̌ejmé, že se vojáci v terénu úplně neřídili poučkami z př́íruček.

\section{Okop pro více stojících střelcu}

Tento typ není přímo popsán v příručkách, ale vyskytl se jak zde, tak i na lokalitě Wallberg v Německu ve spolkovém státě Severní Porýní-Vestfálsko (Müller-Kissing 2015, obr. 8 na s. 190). V příručkách je popsána pouze delší klikatá zákopová linie. Délka linie v úseku od jednoho ohybu k druhému se pohybuje mezi 10 a 15 metry, š́ř́ka má činit $80 \mathrm{~cm}$ při okraji a $40 \mathrm{~cm}$ u dna, hloubka se uvádí až $200 \mathrm{~cm}$, ale v tom př́ípadě musí být zákopová linie vybavena střeleckými výklenky a být napojena na okopy pro dva stojící střelce. Dle příručky měli čtyři muži vyhloubit 10 metrů linie za jeden den (Oberkommando des Heeres 1944, blatt 1-3).

Na lokalitě se nacházejí tři objekty, které je možné interpretovat jako okopy pro více stojících střelců. Dva objekty se nachází v malé skupince objektů mezi oběma hlavními skupinami, od Hradiska jsou vzdáleny 500 metrů přibližně jihozápadním směrem. V jednom případě (obj. č. 744) se jedná o př́mou linii o délce $17 \mathrm{~m}$, druhý (obj. č. 746) představuje pravoúhle lomenou linii. Délka delší části dosahuje rovněž $17 \mathrm{~m}$, kratší část je dlouhá přibližně $4 \mathrm{~m}$. Oba objekty mají delší osu orientovanou severovýchodo-jihozápadním směrem, šiřku mají $80 \mathrm{~cm}$ a hloubku $90 \mathrm{~cm}$ (obr. 7). Třetí objekt (č. 713) se nachází jihovýchodně od Hradiska, má poněkud netypický lehce prohnutý tvar a zhruba severojižní orientaci. Dosahuje délky $530 \mathrm{~cm}$, šířku má kolem $50 \mathrm{~cm}$ a hloubku také $50 \mathrm{~cm}$ (obr. 8). V tomto případě je vzhledem ke zvláštnímu tvaru i orientaci objektu možné, že se jedná o sovětský zákop.

\section{Spojovací zákop}

Jedná se o útvar, který měl spojovat okopy pro stojící střelce v jednu souvislou linii. Má mít klikatý tvar. Mohl být ve dvou variantách - pro stojící vojáky (rozměry odpovídají předchozímu 
typu) nebo pro přikrčené vojáky (liší se hloubkou, která dosahuje jen $50 \mathrm{~cm}$ - obr. 3:F). Za dvě hodiny měli čtyři muži vykopat deset metrů zákopu pro přikrčené vojáky (Bellona Publications Limited 1969, 4-6; Oberkommando des Heeres 1944, blatt 2).

Typický zákop klikatého tvaru sice nebyl na lokalitě zachycen v delším úseku, ale v jednom místě liniová sonda u Pasohlávek protnula dva liniové objekty, které vůči sobě svírají úhel prribližně 90 stupňů. Jeden z nich (č. K674) dosahuje hloubky $34 \mathrm{~cm}$, a ve vzdálenosti necelých

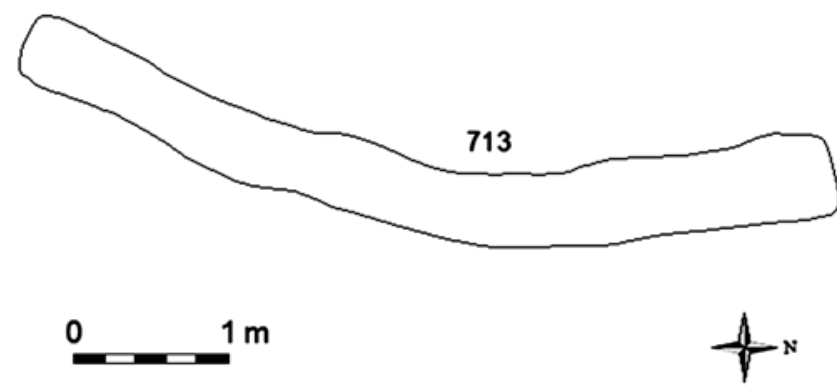

Obr. 8. Objekt č. 713 - okop pro více střelců. Plán ARÚ AV ČR, Brno., v. v. i.

Abb. 8. Objekt Nr. 713 - Graben für mehrere Schützen. Planskizze Archäologisches Institut der Akademie der Wissenschaften der Tschechischen Republik Brno, öffentliche Forschungseinrichtung.

$40 \mathrm{~cm}$ míjí dva až tři okopy pro stojící střelce (jeden objekt je zachycen pouze v malé části). Druhý objekt (obj. č. K678) sice končí v prostorách sondy, ale vzhledem k jeho menší hloubce (pouze $10 \mathrm{~cm}$ ) je možné, že nebyl kopán př́liš hluboko, a proto mohl mít dno částečně v nadloží (obr. 9). Oba objekty pravděpodobně představují zákop pro přikrčené vojáky.

\section{Okop pro kulomet}

Okop pro obsluhu kulometu představuje poměrně charakteristický a výrazný typ drobné polní fortifikace. V obou př́ručkách se vyskytuje několik typů. Nejčastěji se jedná o různě prohnuté krátké linie o délce maximálně $320 \mathrm{~cm}$. Přitom existovaly tři varianty - první byla jednou prohnutá linie (tvar výseče mezikruží), vrchol prohnutí byl odvrácen od nepřítele. Při délce $250 \mathrm{~cm}$ měl objekt jen střeleckou část (obr. 3:D), při delší variantě $(320 \mathrm{~cm})$ měl objekt na obou koncích hlubší kryty pro obsluhu kulometu. Druhou variantu představovala dvakrát prohnutá linie, která se od první lišila $\mathrm{v}$ tom, že úkryt pro vojáky byl pouze na jednom konci objektu. V mladší př́ručce se uvádí ještě třetí varianta se dvěma kryty, které jsou vyhloubeny na obou koncích okopu do jeho zadní stěny. Výsledný tvar připomíná tvar písmena „V“. Každá varianta měla před střeleckou částí okopu vyhloubenou plošinku o hloubce $20 \mathrm{~cm}$, na které měl být umístěn kulomet. Šířka všech variant činí standardních $80 \mathrm{~cm}$, hloubka střelecké části dosahuje $140 \mathrm{~cm}$, hloubka úkrytu měla být 180 až $200 \mathrm{~cm}$. Tři muži měli okop připravit za čtyři hodiny (Bellona Publications Limited 1969, 12-13; Oberkommando des Heeres 1944, blatt 9-10).

Tvar výseče mezikruží mají tři objekty, dva mají tvar velice podobný tomu, který je vyobrazen v příručkách, tedy mírně prohnutý. Objekt č. 499 dosahuje délky přibližně $220 \mathrm{~cm}$, objekt č. 500 byl dlouhý zhruba $250 \mathrm{~cm}$ (obr. 10). Šířka obou objektů je maximálně $50 \mathrm{~cm}$, hloubka není známa. Třetí objekt (č. K680) měl podkovovitý tvar s konci poněkud více protaženými (obr. 11). Objekt je dlouhý $260 \mathrm{~cm}$, hluboký $66 \mathrm{~cm}$ a průřez má šířku $60 \mathrm{~cm}$. Problematická je orientace objektů č. 499 a K680 - oba jsou orientovány na střelbu severozápadním směrem, tedy spíš na německé pozice. Je tedy možné, že se jedná o sovětské okopy, což podporuje i několik nábojnic sovětského typu Mosin, které byly nalezeny v objektu č. K680. Kulometným hnízdem by snad mohl být ještě objekt č. 714, který má půlkruhový tvar a délku necelých $240 \mathrm{~cm}$, za předpokladu dokumentace okopu na úrovni plošinky pro lafetaci zbraně. Podobný objekt je znám i z pozic 


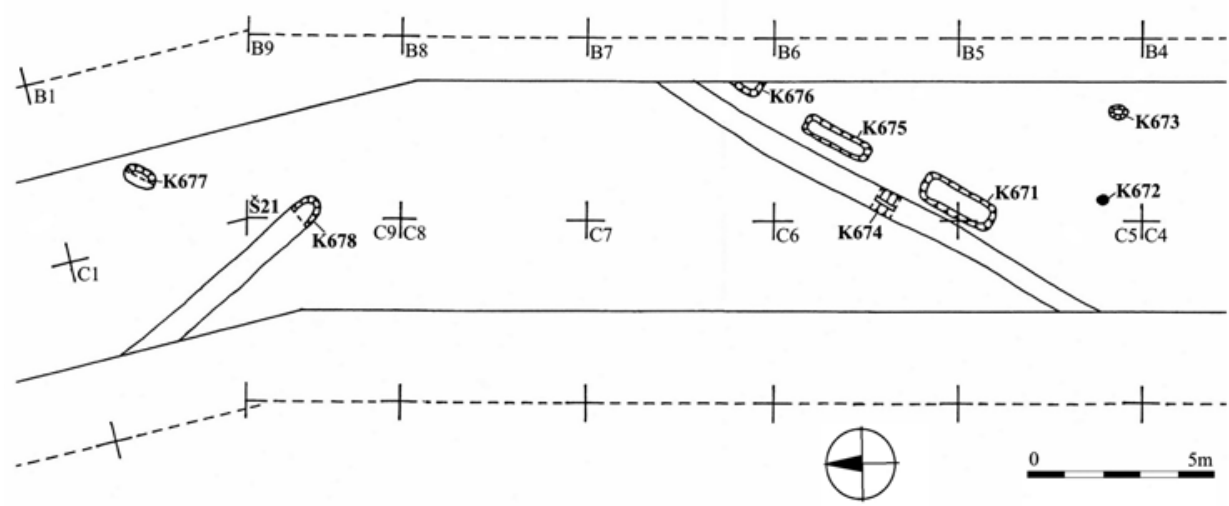

Obr. 9. Objekty č. K671 až K678 - dva až tř̌i okopy pro dva stř̌elce (K671, K675 a K676), kráter (K672) a snad mělký spojovací zákop (K674 a K678). Plán ARÚ AV ČR, Brno, v. v. i.

Abb. 9. Objekte Nr. K671 bis K678 - zwei bis drei Gräben für zwei Schützen (K671, K675 und K676), Krater (K672) und wahrscheinlich flacher Verbindungsgraben (K674 und K678). Planskizze Archäologisches Institut der Akademie der Wissenschaften der Tschechischen Republik Brno, öffentliche Forschungseinrichtung.

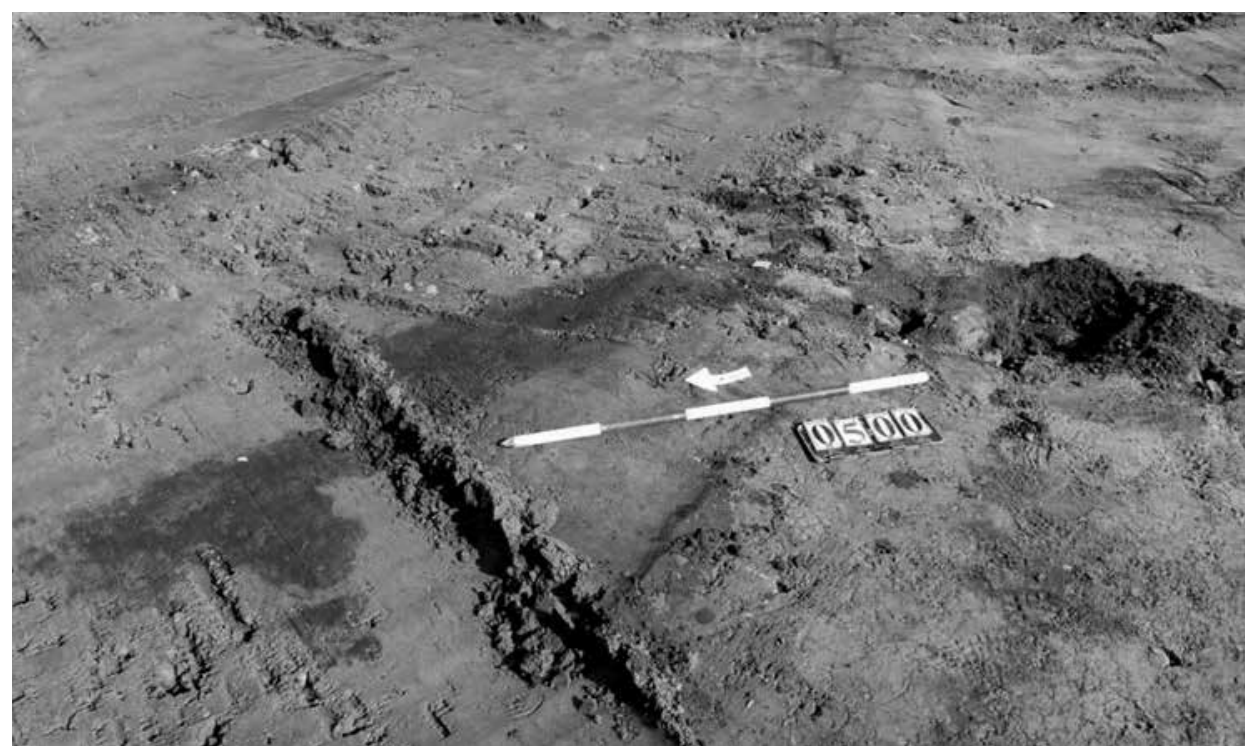

Obr. 10. Objekt č. 500 - okop pro kulomet. Foto ARÚ AV ČR, Brno, v. v. i.

Abb. 10. Objekt Nr. 500 - Graben für Maschinengewehr. Foto Archäologisches Institut der Akademie der Wissenschaften der Tschechischen Republik Brno, öffentliche Forschungseinrichtung.

Hohe Warte u Detmoldu (Müller-Kissing 2015, 189, obr. 4 na s. 188). Při předpokládaném dostřelu kulometu MG-42 přibližně 1200 metrů by měl zde umístěný kulomet dostřel na kraj vsi Mušov a silnici Mušov-Pohořelice.

\section{Kryt pro spojaře}

Speciální kryty pro spojaře jsou uváděny pouze v mladší prŕíručce. Mělo se jednat o objekty tvaru „L“ o vnější délce strany $200 \mathrm{~cm}$ a hloubce $180 \mathrm{~cm}(140 \mathrm{~cm}$ v prostorech střeleckých stupňů). Radiostanice měla být umístěna v místě lomu objektu (obr. 3:E). Dva muži měli objekt 


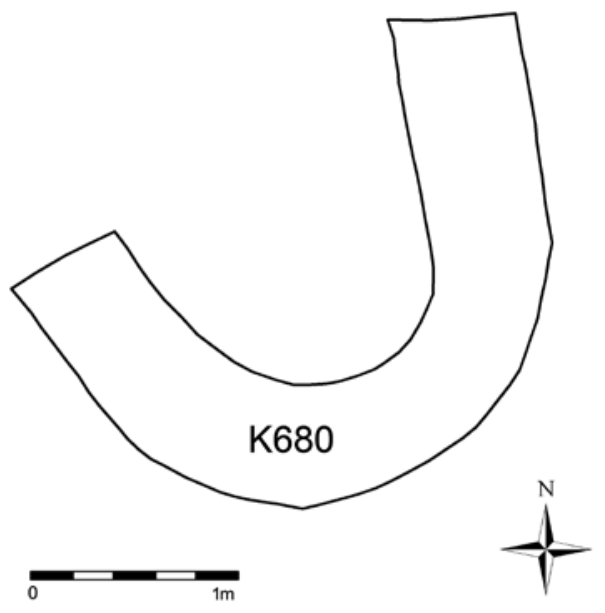

Obr. 11. Objekt č. K680 - pravděpodobně sovětský okop pro kulomet. Plán ARÚ AV ČR, Brno, v. v. i.

Abb. 11. Objekt Nr. K680 - wahrscheinlich sowjetischer Graben für Maschinengewehr. Planskizze Archäologisches Institut der Akademie der Wissenschaften der Tschechischen Republik Brno, öffentliche Forschungseinrichtung.

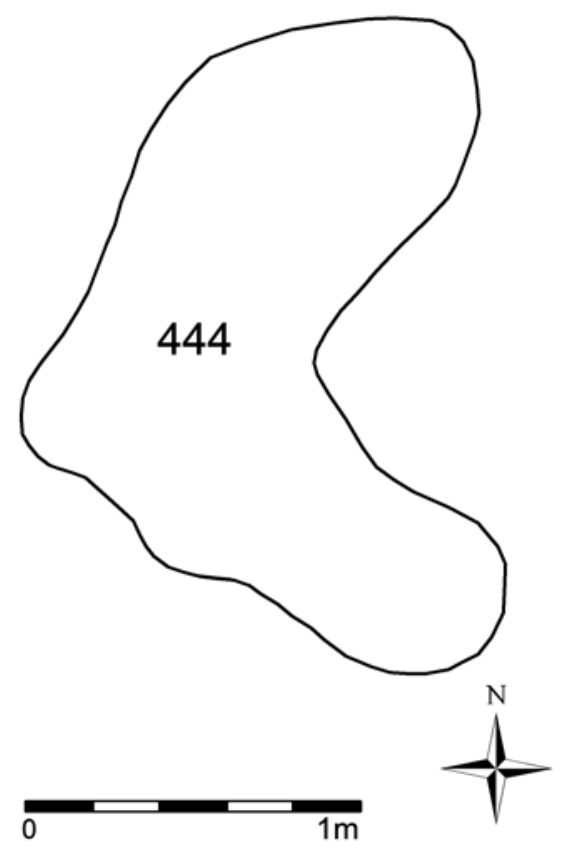

Obr. 12. Objekt č. 444 - kryt pro spojaře. Plán ARÚ AV ČR, Brno, v. v. i.

Abb. 12. Objekt Nr. 444 - Unterstand für Funker. Planskizze Archäologisches Institut der Akademie der Wissenschaften der Tschechischen Republik Brno, öffentliche Forschungseinrichtung. vyhloubit za pět hodin práce (Oberkommando des Heeres 1944, blatt 6).

Tomuto typu krytu by mohl odpovídat objekt č. 444, který má pravoúhle lomený tvar (jako jediný dokumentovaný na celé lokalitě). Délka jednoho ramena se pohybuje kolem 160 až $170 \mathrm{~cm}$, šíŕka $70 \mathrm{~cm}$. Hloubka není známa (obr. 12).

\section{Okop pro střední minomet}

Jedná se o kruhový objekt, od kterého vycházejí dvě krátké chodby sloužící jako úkryt pro obsluhu minometu (obr. 3:G). Průměr okopu činí $160 \mathrm{~cm}$, hloubka kruhové části dosahuje $160 \mathrm{~cm}$, chodby měly být zahloubeny až $200 \mathrm{~cm}$ pod úroveň terénu. Pět vojáků mělo celý objekt vytvořit za šest hodin, v časové tísni měli za tři hodiny vykopat pouze kruhový okop pro minomet (bez postranních chodeb). Tento typ polní fortifikace je zmiňován pouze $\mathrm{v}$ mladší príručce (Oberkommando des Heeres 1944, blatt 19).

Objekt, který by mohl být okopem pro střední minomet, byl pouze fotograficky dokumentován při výzkumu v roce 2008. Jedná se o kruhový objekt o průměru mezi jedním a dvěma metry, se dvěma postranními chodbami, které z kruhového půdorysu vycházejí zhruba naproti sobě. Bohužel přesnější rozměry nejsou známy (obr. 13).

\section{Dělostřelecké krátery}

$\mathrm{Na}$ lokalitě se podařilo dokumentovat také několik objektů, které by mohly vzniknout při dopadu dělostřeleckých granátů. Jedná se mísovité objekty různého průměru. Př́íkladem takového kráteru může být objekt č. 747 o průměru $100 \mathrm{~cm}$ a hloubce $30 \mathrm{~cm}$ (obr. 14), objekt č. 726 o průměru $34 \mathrm{~cm}$ a hloubce $10 \mathrm{~cm}$ nebo objekt č. K672 o průměru $27 \mathrm{~cm}$ a hloubce $6 \mathrm{~cm}$ (obr. 9).

\section{Závěr}

Během terénních výzkumů v okolí Hradiska u Mušova a u Pasohlávek se podařilo odkrýt řadu objektů, které pomáhají připomenout polozapomenuté boje, jež v této oblasti probíhaly na samém závěru druhé světové války. Vysoký počet různých okopů dokumentovaných na poměrně malé prozkoumané 


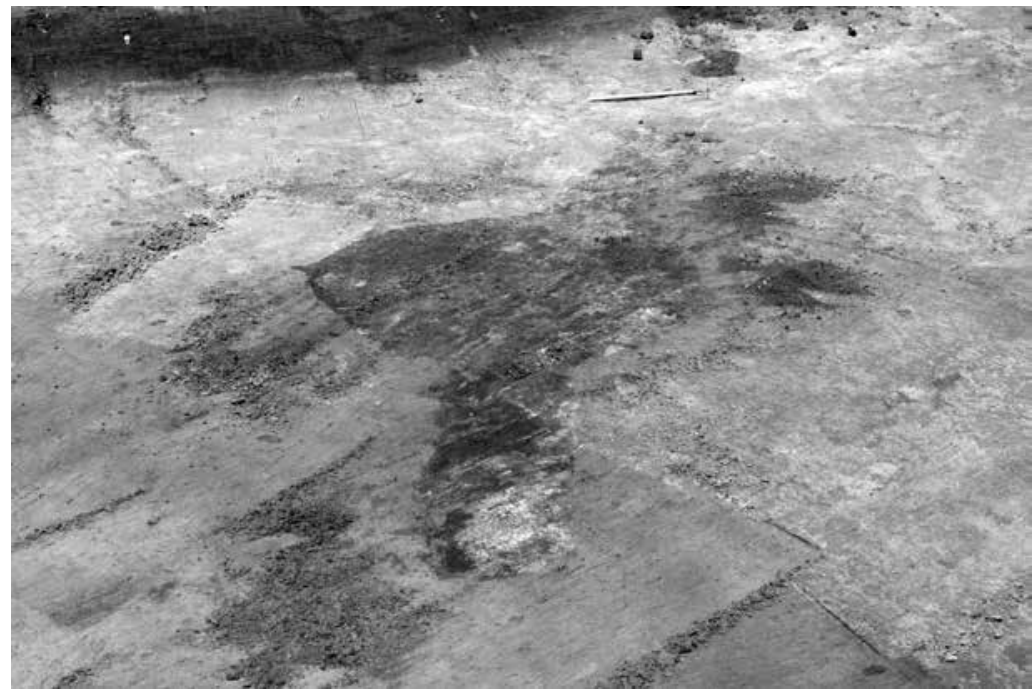

Obr. 13. Neočíslovaný objekt - okop pro střední minomet. Foto ARÚ AV ČR, Brno, v. v. i.

Abb. 13. Nicht nummeriertes Objekt - Graben für mittleren Minenwerfer. Foto Archäologisches Institut der Akademie der Wissenschaften der Tschechischen Republik Brno, öffentliche Forschungseinrichtung.

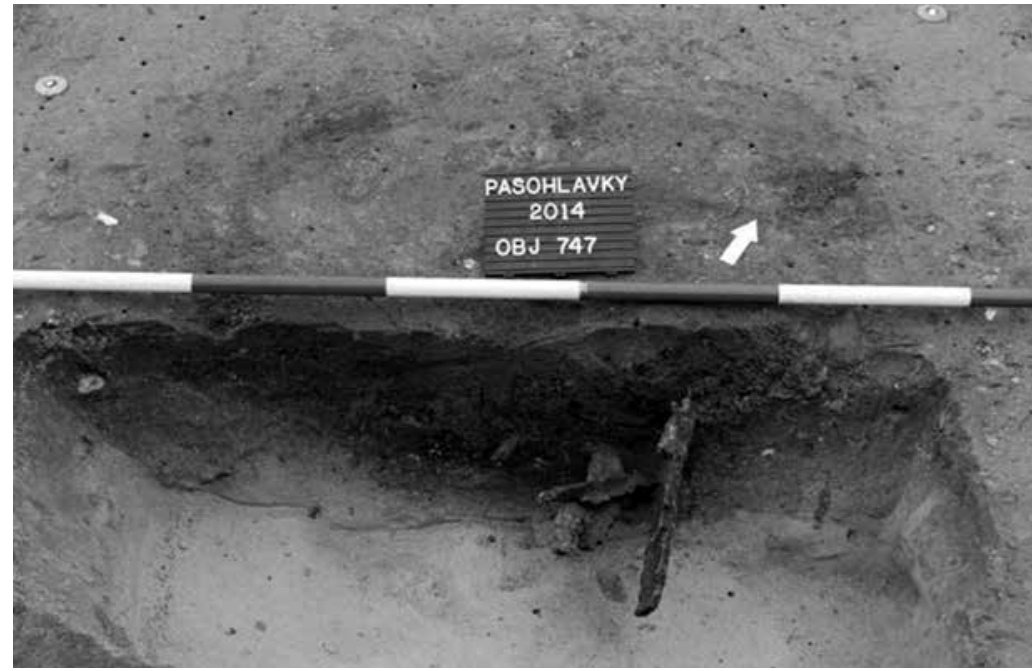

Obr. 14. Objekt č. 747 - kráter po dopadu dělostřelecké munice. Foto ARÚ AV ČR, Brno, v. v. i.

Abb. 14. Objekt Nr. 747 - Krater von einem Artilleriemunitionseinschlag. Foto Archäologisches Institut der Akademie der Wissenschaften der Tschechischen Republik Brno, öffentliche Forschungseinrichtung.

ploše nasvědčuje tomu, že zde německý wehrmacht vynaložil značné úsilí na obranu a krytí svého ústupu do amerického zajetí.

Předběžně se podařilo interpretovat až 65 objektů, které lze dle funkce rozdělit do osmi kategorií (zvláštní kategorii tvoří tř̌i krátery po dopadech dělostřeleckých granátů). Nejčastěji jsou zastoupeny obdélné okopy pro dva klečící nebo stojící střelce (až ve 46 případech), ostatní 
typy objektů nejsou zdaleka tak četně zastoupeny. Podařilo se dokumentovat také několik okopů pro těžší zbraně - okopy pro kulomet nebo minomet. Pozoruhodná je nejednotná velikost jednotlivých objektů a odlišnost rozměrů od údajů uvedených $\mathrm{v}$ příručkách. $Z$ toho lze usuzovat, že vojáci se v praxi při stresových situacích a hrozícím nebezpečí od nepřítele pravděpodobně příliš neřídili pokyny z příruček, důležité pro ně bylo především připravit kryt pro sebe. Zvláštní je také přítomnost delších lineárních střeleckých zákopů, které nejsou z dostupných př́ruček známy. Může jít o improvizaci velitele nebo o nedokončenou delší zákopovou linii.

Další poznatky o systému německé obrany i o bojích probíhajících na lokalitě může přinést terénní výzkum či nedestruktivní průzkum dalších ploch v oblasti. Pomoci mohou i některé hůr̆ dostupné dobové prameny. V neposlední řadě mají jistý potenciál i prostorové analýzy, jelikož pro kvalitní organizaci obrany je potřeba dostatečný rozhled směrem k nepříteli.

\section{Prameny a literatura}

BELLONA PUBLICATIONS LIMITED 1969: Merkblatt 57/5 (Anhang 2 zur H. Dv. 1a, Seite 57, lfd. Nr. 5). Bildheft Neuzeitlicher Stellungsbau. Vom 15. 9. 42. Nachdruckeinschl. eingearb. Berichtungen nach dem Standevom 11. 3. 43. German Field Works of World War II. Hawthorn Hill.

BORTLÍKOVÁ, I., 1988: Osvobození okresu Břeclav Rudou armádou v roce 1945 ve světle obecních kronik. Diplomová práce, rkp. ulož. v SOkA Břeclav.

HOLEČKOVÁ, S., 2014: Ztráty 7. gardové armády v bojích o Brod nad Dyjí, Ivaň, Mušov a Pasohlávky Verluste der 7. Gardearmee in den Kämpfen um Goldenfurth (Brod nad Dyjí), Eibes (Ivaň), Muschau (Mušov) und Weißstätten (Pasohlávky), JM 50, 310-341.

KOMORÓCZY, B., 2000: Mušov (k. ú. Pasohlávky, okr. Břeclav), PV 41 (1999), 145-147.

MOSHENSKA, G., 2012: The Archaeology of the Second World War. Uncovering Britain's Wartime Heritage. Barnsley.

MÜLLER-KISSING, J., 2015: Durch diese hohle Gasse muss er kommen. Deutsche und amerikanische Feldbefestigungen von 1945 bei Detmold-Berlebeckam Teutoburger Wald, Mitteilungen der Deutschen Geselschaft für Archäologie des Mittelalters und der Neuzeit 28, 187-194.

OBERKOMMANDO DES HEERES 1944: Merkblatt 57/5. Bildheft Neuzeitlicher Stellungsbau. Vom 1. Juni 1944.

RAK, M., 2013: Archeologie konfliktů 20. století. In: Archeologie 19. a 20. století. Př́stupy - Metody - Témata (Vařeka, P., ed.), 115-136. Plzeň.

SAUNDERS, N. J., 2010: Killing time. Archaeology and the First World War. Brimscombe (2nd edition).

SCHILDBERGER, V., 1987: Organizace, výzbroj a označení fašistických vojsk na Moravě v dubnu a květnu 1945. In: Morava v boji proti fašismu I. Studie k dějinám Moravy v 19. a 20. století I. (Halama, V.-Mikulka, J., edd.), 200-217. Brno.

TÖPFER, H., German Tactical Manual. Dostupné z: http:/www.gr916.co.uk/assets/pdfs/GermanTacticalManual.pdf, cit. 26. 11. 2016.

WAR DEPARTMENT 1943: Special Series, No. 9., The German Squad in Combat.

WAR DEPARTMENT 1945: Technical Manual TM-E-30-451. Handbook on German Military Forces.

Память народа::Поиск документов частей. Dostupné z: https://pamyat-naroda.ru/documents/ view/?id=130223120\&backurl=division\%5C409\%20сд\%3A\%3Abegin_date\%5C28.04.1945\%3A\%3Aend_date\%5C28.04.1945, cit. 19. 11. 2016.

\section{Zusammenfassung}

\section{Vorläufige Interpretation der Feldbefestigungsobjekte der deutschen Wehrmacht bei Pasohlávky (Bezirk Brno-Land)}

Bei den in den letzten Jahren zwischen den Gemeinden Pasohlávky (Bezirk Brno-Land) und den südlichen Bergfüßen der Anhöhe Hradisko (Burgstall) bei Mušov durchgeführten Rettungsgrabungen ist es unter anderem gelungen, Relikte freizulegen, die auf Kriegsereignisse vom Ende des Zweiten Weltkrieges schließen lassen. Nach dem 20. April 1945 wurde von der deutschen 
Wehrmacht im untersuchten Gebiet ein System von Feldbefestigungen angelegt. Am 23. April hat die Rote Armee diesen Raum erreicht, und beim ersten Angriff ist es ihr auch gelungen, Hradisko einzunehmen. Die Wehrmacht hat die Ortschaft Pasohlávky gehalten. Daraufhin folgten ungefähr eine Woche lang schwere Kämpfe, in denen Pasohlávky und wohl auch Hradisko mehrere Male ihren Besitzer gewechselt haben, trotzdem hat sich die Situation letztendlich nicht verändert. Ab dem 1. Mai herrschte dann Ruhe an der Fundstelle, die Rote Armee hielt Hradisko und die Wehrmacht Pasohlávky, beide Armeen hatten sich in ihren Stellungen verschanzt. Weitere Kämpfe sind am 7. Mai ausgebrochen, als die Sowjets Pasohlávky endgültig eroberten und weiter nach Böhmen vorrückten.

Der vorliegende Beitrag richtete seine Aufmerksamkeit auf eine vorläufige Interpretation der jeweiligen eingetieften Feldbefestigungsobjekte. Dazu dienten zwei Ausgaben des zeitgenössischen, in deutscher Sprache verfassten Pionierhandbuchs Bildheft Neuzeitlicher Stellungsbau, die ältere Ausgabe erschien im März 1943 (verfügbar in einer englischen Übersetzung aus den sechziger Jahren), die jüngere im Juni 1944. In beiden Handbüchern findet man Abbildungen von verschiedenen Schützengräben für Soldaten sowie für schwerere Waffen einschließlich Abmessungen, Bauzeit bzw. Ablauf der Arbeiten. Mithilfe dieser Handbücher ist es gelungen, bis zu acht verschiedene Objekttypen auszumachen. Da aber nicht alle Objekte ausgeschachtet wurden, ist bei vielen von ihnen unbekannt, wie tief sie sind, gegebenenfalls welche Form sie genau haben, was bei einer genauen Interpretation dieser Objekte Komplikationen verursachte.

Der gängigste Typ ist ein kleineres rechteckiges Objekt für zwei stehende oder kniende Schützen, das in bis zu 46 Fällen dokumentiert wurde, wenn auch bei 25 Objekten ihre unbekannte Tiefe eine Interpretation erschwert hat. Drei weitere rechteckige Objekte entsprechen aufgrund ihrer geringen Tiefe (ca. $20 \mathrm{~cm}$ ) Gräben für einen liegenden Schützen. Zweimal wurden kleine rechteckige Objekte verzeichnet, die ein Graben für einen knienden oder stehenden Schützen sein könnten. Drei weitere lineare Gebilde funktionierten wahrscheinlich als Schützengräben für die gesamte Mannschaft. Bei einem Fall handelt es sich wohl um einen nicht fertiggebauten Verbindungsgraben für geduckte Soldaten. Ein besonderer Objekttyp ist ein kleiner Unterstand für Funker, der die Form des Buchstabens „L“ hat. Von den Gräben für schwerere Waffen konnten drei bis vier Gräben für Maschinengewehre dokumentiert werden, wobei es aber in zwei Fällen im Hinblick auf die Feuerrichtung möglich ist, dass es sich um sowjetische Objekte handelt. Ein Objekt könnte ein Graben für einen mittleren Minenwerfer darstellen. In drei Fällen wurden die Böden von Kratern verzeichnet, die von Granatwerfereinschlägen stammten. Bemerkenswert ist die uneinheitliche Größe der einzelnen Objekte und die Verschiedenheit der Abmessungen von den in den Handbüchern gemachten Angaben, die Soldaten haben sich in der Praxis wahrscheinlich nicht allzu sehr nach den in den Handbüchern aufgeführten Vorgaben gerichtet.

Weitere Erkenntnisse über das deutsche Verteidigungssystem und über die an der Fundstelle erfolgten Kämpfe können durch eine Geländegrabung oder eine zerstörungsfreie Untersuchung weiterer Flächen in dem betreffenden Gebiet gewonnen werden. Hilfreich können auch einige schlechter verfügbare zeitgenössische Quellen sein. Nicht zuletzt haben auch Raumanalysen ein gewisses Potenzial, da für eine qualitativ gute Organisation der Verteidigung eine ausreichende Sicht in Richtung des Feindes erforderlich ist.

Mgr. Jiř́ Zubalík, Ústav archeologie a muzeologie Filozofické fakulty Masarykovy univerzity, Arna Nováka 1, 60200 Brno, Česká republika, zubalik.jiri@gmail.com

Mgr. Balázs Komoróczy, Ph.D., Archeologický ústav AV ČR, Brno, v. v. i., Čechyňská 363/19, 60200 Brno, Česká republika,komoroczy@arub.cz

Mgr. Miroslav Lukáš, Archeologický ústav AV ČR, Brno, v. v. i., Čechyňská 363/19, 60200 Brno, Česká republika,lukas@arub.cz

Mgr. Marek Vlach, Ph.D., Archeologický ústav AV ČR, Brno, v. v. i., Čechyňská 363/19, 60200 Brno, Česká republika,vlach@arub.cz 
